\title{
India to become a Global Power: Issues and Challenges
}

\author{
Rameez Raja \\ ICSSR Fellow, Ph.D. Student, Department of Political Science, Jamia Millia Islamia, New Delhi, India \\ E-Mail: rameezrajaa23@gmail.com
}

\begin{abstract}
Numerous models have played an outstanding role in understanding the success of many states across the globe. Additionally, various reform movements as well as the revolutions have helped the developed states to improve or change their political and economic institutions that eventually terminated into political stability, economic prosperity and finally achieved the global power status. These revolutions helped other states too to adopt democratic principles in order to achieve economic prosperity. However, despite India having adopted the democratic principles in 1947, implementation of the LPG model in 1991, and going nuclear in May 1998, it lacks a global power status due to varied reasons. The poverty, unemployment, weak industrial sector, poor economic and education policies, border disputes, and inability to tackle the insurgency are other factors that thwarted India to gain a global power status. Simultaneously, this paper will display the importance of inclusive political and economic institutions for achieving a global power status.

Keywords: India, Democracy, Global Power, Poverty
\end{abstract}

\section{INTRODUCTION}

A lot of scholarly work has been conducted on the developed as well as on the underdeveloped states across the globe. The most important work Why Nations Fail is jointly contributed by two economists, Daron Acemoglu and James Anderson. These authors have rejected the cultural hypothesis, the geography hypothesis, and the ignorance hypothesis for the economic prosperity of the states. They argued that extractive political and economic institutions are the primary factors that eventually culminated into the failure of the states. Also, Acemoglu and Anderson argue that inclusive political and economic institutions are the main factors that helped states to gain economic prosperity and political stability of the many states which are currently the developed states of the world. In the Indian context, Bharat Karnad in his piece Why India is not a Great Power argued that despite India have achieved an emerging power status due to soft power determinism, India's weak hard power capability including the absence of political vision and will have restricted India from achieving the global/great power status. Bharat Karnad in his new piece Staggering Forward: Narendra Modi and India's Global Ambitions criticized the foreign and security policies of Modi government. Karnad argues that in case Modi will return to power in next parliamentary elections, it would be a setback for India to achieve a global power status due to Modi's flawed foreign and security policies over the last four years.

Political scientist, John Mearsheimer in his book The Tragedy of Great Power Politics argues in contrast with
Karnad. Mearsheimer (2014) argues that military capability alone cannot transform a state into a great power. Nuclear and conventional weapons are the tools of military power rather than the elements of great power status. He states that a robust economy is a primary factor for achieving a global power status. Also, Mearsheimer (2014) argues that achieving a great power status, states should avoid wars and focus on economic development. French strategists, Andre Beaufre and Pierre Marie Gallois argue that due to the tremendous destructive power of nukes, there is no need to match the adversary bomb-for-bomb and unlike conventional weapons, numerical ratios are immaterial (Salik, 2016, 86). Thus, India should avoid nuclear arms race and divert the rich resources for economic prosperity. Additionally, the renowned Princeton University economist, Dr Atif Mian argues that it is 'exports' that might help developing or poor states to develop economically. The 'export or die' was the key mantra that East Asian states approved, signifying the powerful equation of trade with national survival (Paul, 2014, 22).

Parama Sinha Palit (2017) in her piece Analysing China's Soft Power Strategy and Comparative Indian Initiatives argues that cultural and public diplomacy are one of the most developed and structured elements of soft power strategy that is currently progressive in China. Palit (2017, $\mathrm{xx})$ argues that China is ahead of India in delivering better qualities of lives to its citizens. No Indian newspaper has yet stepped overseas unlike China Daily and the China Central Television (CCTV) have firm footprints in almost all parts of the world (Palit 2017: 299). As far as higher education institutions are concerned, China's universities are rapidly marching upward in global education rankings. Palit (2017, 298) argues that India appears to be falling way behind China in this regard, particularly in its failure to internationalise. Although Indians have proficiency in English that could have attracted Western educational institutions, the Indian education system has failed to attract the overseas students as well as the foreign faculty due to its extractive educational institutions.

Along with the economic power, military capability is also considered to be the most significant element of superpower or global power. Both India and Pakistan including China are busy in the arms race in South Asia to match or dominate each other, however, unresolved disputes are a great source of alarm in the region. India and Pakistan fought many wars on Kashmir that resulted in the destruction of lives and rich resources. The book 
International Relations Theory and South Asia: Security, Political Economy, Domestic politics, Identity, and Images edited by E. Sridharan talks about the resolution of conflicts in South Asia. The authors provided many perspectives for the conflict resolution, for instance, Sridharan (2015) mentioned the 'common project school' outlined by Mircea Malitza. The book concludes that conflict resolution is feasible through economic ties rather than by military means. However, in the context of India and Pakistan, economic ties failed to resolve the disputes, too. Kanti P. Bajpai and Harsh V. Pant's edited book India's National Security: A Reader displayed how to curb the insurgency and militancy. In this book, Rajesh Rajagopalan (2013) argues that India lacks expertise in counterinsurgency operations and military means is not a solution for curbing insurgency and militancy, the solution per se is political.

This study explains why India is not a global power and what India should do to uplift its economy? Also, this study analysed the problems faced by India in resolving the conflicts with Pakistan and China. This study understands that India should focus on peace research rather than strategic studies for resolving the conflicts. Finally, this study finds that inclusive political and economic institutions might help India to achieve a global power status. This study tested the above-mentioned hypotheses with the help of studies by political scientists, strategists, deterrence optimists, proliferation pessimists, ex-military officials, economists, journalists, and peace activists.

\section{ECONOMIC FACTOR}

It is assumed that India might become a global power in case it succeeded to implement the inclusive democratic and liberal economic principles. It is largely believed by economists that politics is crucial for explaining world inequality (Acemoglu and Robinson, 2013, 68). The weak and corrupt governments hardly appreciate the innovations of the people due to many reasons. For instance, Pakistan did not acknowledge the Nobel Laureate Dr Abdus Salam's contribution to science who might have transformed Pakistan into a prosperous state. Recently, the government of Pakistan was forced by Islamists to remove the renowned economist Dr Atif Mian's name in the Economic Advisory Council to the prime minister that finally resulted into the resignation of two more economists from the same council (Dawn, 2018). The only reason which forced Pakistan to ignore Dr Salam and Dr Mian's contribution to science and economics are their Ahmadi Muslim faith which according to Islamists is non-Muslims in Pakistan. The religious determinism has prevented the governments to create political stability and economic prosperity in Pakistan.

India has adopted, praised the democratic principles and secularism has been approved in Indian constitution to provide an equal opportunity to all citizens in India. However, India's mixed economy struggled in past to create a conducive and equal environment for people to uplift their economy. The Harvard University professor, Gita Gopinath was recently appointed as the Chief Economist of International Monitory Fund (IMF). Earlier in 2016, her appointment as financial advisor to Chief Minister of Kerala, Pinarayi Vijayanhad created discrepancy because some communist leaders questioned the CPM-led state government for roping in a person who was more into the market economy and liberal policies (The Times of India, 2018). The liberalization, privatization and globalization (LPG) model is a landmark factor for capitalists/democrats for economic prosperity while communists prefer the socialist pattern of economic policies where state control all the financial institutions. India has endorsed the LPG model in 1990s that resulted in the free flow of market in the shape of Multi-National Corporations (MNCs). However, the gap between the haves and have-nots in India has increased although India has adopted the LPG model since 1991. Several studies highlighted the problems related to India's economic system that widened the gap between the haves and have-nots in India.

The recent study by researchers at Brookings Institution has predicted that 'India is perhaps no longer home to the highest number of people living in extreme poverty'. However, the study has compared India (73 million) with Nigeria (87 million) people living in extreme poverty in May 2018. According to the World Bank, if a person is living on less than 1.90 international dollars a day is declared extremely poor.

Poverty and unemployment are the main issues in India. India's neighbour China has managed to help the extremely poor people due to the shifting of jobs in the formal enterprise, investments in human capital, relatively equal land ownership in rural areas and targeted interventions. However, India is struggling to create job creation in rural areas where people are mostly struggling with poverty and unemployment.

Samir Saran (2018) argues that India needs four steps to put in place for achieving a global power status. First, India should define its China policy. Second, India should develop a clear policy with the United States. Third, India must rethink its engagement with its neighbours, particularly around two existing regional architectures. Fourth and last, India must engage more vigorously with the global institutional framework.

China is ahead of India in economic and military affairs. The border dispute between India and China and the inability to settle this has a negative impact on India's ambition to achieve a global power status. Mearsheimer $(2014,382)$ argues that China is not offensive as compared to the United States. The United States has passed bucks to India to fulfil its strategic interests that resulted in the intrusion of Chinese troops into Indian Territory. Also, India's intervention in the South China Sea with the support of the United States has provoked China to shift its defensive policy to aggressive toward India. Mearsheimer $(2014,382)$ argues that it is China's neighbours that have 
been initiating most of the trouble in recent years. Recently, India and Japan agreed to sign a maritime pact to monitor Chinese warships in Asia-pacific (Sputnik News, 2018). The study understands that China's rising as a superpower is a source of alarm for many that is why its neighbours are creating troubles and hurdles to its capabilities with the support of the United States.

The respective political parties are more inclined to rule India rather than to guide India toward a global power status. The South Asian Association for Regional Cooperation (SAARC) and the Bay of Bengal Initiative for Multi-Sectoral Technical and Economic Cooperation (BIMSTEC) has turned into a medium of talk rather than action. India has rejected to attend the 2016 SAARC meeting in Pakistan due to cross-border infiltration (India Today, 2016). However, such initiatives might hardly enforce Pakistan to halt its Jihad policy against India. According to recent reports, the militancy in Kashmir has been increased since the militant, Burhan Wani was killed in summer 2016 by Indian security forces (Rashid 2018). Similarly, India is not interested to become a member of China-Pakistan Economic Corridor (CPEC) because it passed through Gilgit-Baltistan in Pakistan occupied Kashmir (POK) which challenges India's sovereignty, Union defence ministry said (Pandit, 2018). Such unresolved disputes have added fuel to the fire where India is struggling to trust China and Pakistan in order to promote economic cooperation and trade in the region. The study understands that the settlement of unresolved disputes is vital for bringing peace in the region which would eventually help India to focus more on economic development rather than on military improvement. The countless amount of money has been spent by India on military capability in order to match China and dominate Pakistan.

The flawed economic policies have also restricted India to achieve a global power status. The abrupt implementation of demonetization in 2016 by BJP government resulted into the death of 100 innocent people in India. The Supreme Court of India asked the BJP government about the success of the demonetization. According to the Prime Minister Office, the demonetization was implemented to stop militant funding in Kashmir and to curb the black money in India. However, the case is dissimilar, the BJP government failed to achieve the dual targets due to demonetization. Interestingly, demonetization has slowed down the economic growth in various sectors in India. The author of a book Demonetization and Black Economy, Arun Kumar (2018) argues that 'demonetization is a policy-induced selfgoal which damaged several institutions.' Kumar (2018) further argues that unorganized sector was hit hard by demonetization. The impact of note-ban is so deep that the nightmare continues for India's informal economy. Also, the recent report of the Reserve Bank of India (RBI) hints that demonetization did not help in curbing black money circulating in the market (Indiatimes, 2018).
Aishwarya Krishnan (2018) stated that 'the ban on old notes is being cited as one of the key contributors to the economic slowdown. With the gross domestic product (GDP) for the April-June quarter slipping to $5.7 \%$, the reality of the economic slowdown could not be ignored. The World Bank has reduced the India GDP growth forecast to $7 \%$ for 2017 18 owing to demonetization and GST (Goods and Service tax). The slowdown is being cited as a delayed consequence of demonetization by the World Bank and while there are various other reasons at play, the steep decline has been credited to be an effect of demonetization.'

The taxation is assumed as an important element in helping to raise the standard of living in a country. However, in India, smaller companies face a higher effective tax rate compared to larger corporates (Singh, 2018). It is estimated that the big corporates benefit from numerous tax exemptions that resulted in tax avoidance. Ram Singh (2018) argues that 'the share of direct taxes in the total tax collection has remained low.' According to World Wealth Report 2018, by Credit Suisse, at least 3,400 Indian have an annual income of more than fifty crore rupees each. However, only 179 of them reported their income to the taxman in AY 2017-18. Also, out of more than 1,500 Indians with an expected annual income of more than one hundred crore rupees each, only 61 reported to the taxman (Singh, 2018). Astonishingly, the haves in India has failed to pay the taxes while have-nots are paying the taxes.

Another sad episode is the labour market in India. The labour market in India is very large, however, it is reported that labours especially migrant labours face pathetic conditions in the state of Gujarat. The migrant labours are from Rajasthan, Madhya Pradesh, Maharashtra, Bihar, Uttar Pradesh, Andhra Pradesh, Odisha, Jharkhand, Assam, and Karnataka. It is estimated that the 40 lakhs to 1 crore are working as labours in Gujarat. The migrant labours became easily exploited by their employers. The very long hours working with low wages and fewer benefits resulted in the poor quality of living of labourers in India. These migrant labours live on roads, slums, or in illegal settlements not served by municipalities. Due to low wages, these labours are not able to improve their living conditions but educated and semi-skilled labours get slightly higher wages than unskilled labours. Overall, factory owners, employers, and traders get benefits as they earn huge profits from wage labour exploitation (Hirway, 2018). Despite that labour rights have been guaranteed by the Inter-State Migrant Workers Act and other Labour Laws in India, the migrant workers have been easily exploited. The Gujarat government remain uninterested to these laws as well as the political sphere is silent about the protection of migrant labour rights in India (Hirway, 2018). It is also reported that the government has not implemented the rules which it has set for industries and employers in Gujarat to give $85 \%$ of jobs to local people in 1990s. The study agreed with the economist Indira Hirway's (2018) analysis that 'the real solution to this issue would be to enforce all relevant labour laws for migrant workers so that segmentation of the labour 
market becomes weak, and workers (local and migrant) get a fair and equal deal in the market.' Also, the study understands that currently, Gujarat is an example of extractive political and economic institutions where migrant labours are suffering due to wage labour exploitation and non-implementation of migrant labour laws by the government.

\section{NO POLICIES JUST SLOGANS}

The Nobel Laureate, Richard Thaler is the father of the socalled 'nudge' theory. The theory demonstrates how people can be persuaded to make decisions that leave them healthier and happy. The book Nudge contributed by Richard Thaler and Cass Sunstein argue that 'By knowing how people think, we can make it easier for them to choose what is best for them, their families and society' (Chu, 2017). The theory was utilized in the UK pension policy and donation of organs in Spain. Also, France and England switched to an opt-out regime. Several states have shown interest to adopt Nudge units like the US, the UK, Denmark, Australia, Canada, and the Netherlands. India too adopted the Nudge theory to help its citizens to make decisions that will make them healthier, wealthy and happy. The prime minister of India, Narendra Modi's two major initiatives 'Give it Up' and 'Swacch Bharat' can be seen as examples of Nudge theory in India. Surrendering Liquefied Petroleum Gas (LPG) subsidy, use of toilets, beti bacho (save the girl child), beti padhao (educate the girl child) are all elements of Nudge in India (India Times 2017). However, rapes of minor to adult girls are common in India. According to police data, nearly 39,000 rapes were reported in India in 2016 (Doshi, 2018). Child rapes jumped 82 per cent that year, to more than 19,000 . There is almost no answer from the government how to protect the girl child. The study finds that beti bacho is just a mere political slogan.

\section{EDUCATION SYSTEM}

Indian education system is not research oriented but functions as a medium of teaching. There are around 1.5 million schools and around 260 million children have attended the school in India today (Dasgupta, 2018). However, the majority of schools are in bad shape with a poor curriculum where teachers are under-qualified. Also, the government educational institutions lack a quality education. Additionally, the main source of alarm in India is unemployment. It is reported that only 7 per cent of Indian engineering graduates are employable (Dasgupta, 2018). India need to focus on careers rather than course. According to Amit Dasgupta (2018), 'World-class education systems do not have an ideological focus but are entirely market driven. Like the market, they anticipate the future and ascertain how best it needs to be navigated. If India's future is to be determined by the quality of education that it offers, mindsets have to dramatically change.'

The higher education in India is also a teaching oriented. From teachers to research scholars, the majority are struggling to publish their study in a reputed journal due to a poor quality of research education in India. Also, Palit (2017) argues that India is struggling to attract Western students and faculty to study and research in India. Recently, the University Grants Commission (UGC) has stated that teachers in central universities may now be dismissed for speaking against the government (The Logical Indian Crew, 2018). A. G. Noorani argues that the freedom of expression is particularly necessary in the academic context and 'the UGC's fiat is unconstitutional'. The main purpose of higher education is research and teachers are a significant part of it. In case, the UGC restricted teachers for critiquing the government, the Indian education system automatically will fall under the category of extractive educational institutions. Acemoglu and Robinson (2013) have explicitly stated that extractive political, economic, and educational institutions would eventually fail the states.

\section{INDUSTRIAL REVOLUTION}

The Glorious Revolution, the Industrial Revolution in England, and the French Revolution in France gave birth to new innovations that finally resulted in a 'creative destruction'. The European people started experimenting for new innovations that eventually benefited both the state and the inventor. The United States too adopted the European industrial model to accelerate the economic growth that finally resulted in prosperity. The same is the case with Japan with the help of its Meiji Restoration. Along with other branches of sciences, nuclear science was also welcomed but only as an element of security by the United States and the UK. There is very less study to support the notion that electricity generated from nuclear reactors is cheap. There is a link between nuclear proliferation and profit. The nuclear industries are selling nuclear equipment to the receiving states only because of a capital accumulation. The countless amount of money has been received by the nuclear industries from India.

Sankaran Krishna $(2007,7)$ argues that nuclear weapons and missile development are today a second-rate science. Obviously, science has changed the world, mostly the Western states, with the emergence of great scientists like Albert Einstein, Isaac Newton, Galileo Galilei, Thomas Alva Edison, Marry Curie, Louis Pasteur, Niels Bohr, Alexander Graham Bell, Michael Faraday, Nicolaus Copernicus, etc. These scientists played an important role in bringing the world together to fight against diseases, natural calamities, and poverty as well as made our life easier and comfortable with the invention of modern technologies that we use in day-to-day life. However, modern technology has also been used as a source of evil and destruction. Such technologies have been developed with the potential of destroying the entire world within a short span of time. The reference here is to weapons of mass destruction, particularly nukes. Einstein, who is known for his unique contribution to science, is the same person, who signed a letter on August 2, 1939, written by Leo Szilard in consultation with two Hungarian physicists, Edward Teller 
and Eugene Wigner. The letter was sent to the US president Roosevelt and it mentioned that the atom bomb should be made before Germany does. However, after the nuclear destruction of Japan in 1945, Einstein realized that signing a letter to Roosevelt was a big mistake. Einstein agreed that 'everything has changed except human thinking' (Raja, 2017).

India has adopted the nuclear science model particularly nuclear weapons development as an element of power and status. Achin Vanaik $(2015,25)$ argues that India's future vision is linked with Big Science which means the institutionalisation of a nuclear energy for a dual-use (civilian/electricity and military/nukes). Nuclear science was perceived by India as the only way to convince its large populations about its achievements in the scientific world. But the majority of people in India happen to live below the poverty line.

The real development includes developments in original scientific research, high technology, the country's general scientific progress, rather than developing a weapon of evil which can kill each and every living creature. It is estimated by the World Bank that in India only 34 per cent has access to toilets and in Pakistan, only 48 per cent has access to facilities and services for the safe disposal of human urine and faeces. In terms of human development, India are far behind most of the nations, with the rank of 130 among 189 nations (UN Human Development Index, 2018). The rivalry is so bad that both states (India and Pakistan) are spending huge amounts of money for nuclear arsenals and less for the eradication of poverty. The unresolved disputes between India and Pakistan and between India and China has restricted these states to focus more on economic development in past. Nevertheless, India has achieved the status of a fast-developing economy after implementation of LPG model but China is moving ahead with India as an Asian Giant because of its soft power determinism, strong economic sector, and military might.

At the inauguration of the Centre for the Fourth Industrial Revolution, the prime minister of India, Narendra Modi had said that India can surprise the world in the next industrial revolution, the 4th Industrial Revolution or 4thIR (TN Ninan, 2018). Modi said that India was moving from 'local solution' to 'global application'. According to TN Ninan (2018) '4thIR is an umbrella term that includes everything from the Internet of Things and Artificial Intelligence to 3D printing and blockchain, and from speciality materials to autonomous vehicles and 5G communications technology. In essence, it brings together digital technology and the physical world to create a new range of products and services. As should be immediately clear, India is not a frontrunner in most of these areas. But India and Indians are beginning to make their contribution to the emerging digital-physical world.' Such type of steps might help India to achieve an emerging global power status in case the 4thIR model will be implemented properly in India.

\section{MILITARY FACTOR}

Rajesh Rajagopalan (2015, 44) explicitly argues that insurgency/militancy cannot be solved by force or military means. Pakistan's jihad policy toward India is supported by its nuclear capability. It is futile to believe that military means will solve the border disputes between India and Pakistan as well as between India and China. Undoubtedly, India is a regional power but nuclear arms race in the South Asian region has eroded the precious resources that could have been utilized in the civilian sector for economic prosperity in India. India is busy in building a strong nuclear force against China that has a negative impact on Pakistan's nuclear force. The triangular nuclear arms race has challenged Kenneth Waltz's nuclear deterrence theory (1981). The few nukes of North Korea have played an important role to deter the United States, however, in the context of India, Pakistan, and China, a robust nuclear force (Mutual Assured Destruction) has been given first priority. The non-nuclear states like Japan, Germany, Australia, New Zealand, South Korea, Singapore and even Malaysia have achieved an economic prosperity due to inclusive political and economic institutions. These states have rejected nuclear weapons as a tool for global power status and provide incentives to people to achieve a high standard of living. In contrast, India has worshipped nuclear science as an element of power, status, and prestige that ultimately resulted in the five nuclear tests in May 1998. Achin Vanaik $(2015,32)$ argues that India's nuclear tests were statusdriven, not threat driven.

The realists, neo-realists and nuke speakers have supported nuclear weapons for security/deterrence, however, the 1999 Kargil war under the nuclear umbrella between India and Pakistan is a setback to deterrence theory. Some sources are of the view that India blasted the Pokhran desert in May 1998 in order to get the permanent seat of United Nation Security Council (UNSC). The nuclear card is not sufficient for India to declare itself a global power or to achieve a permanent membership of the UNSC.

\section{WHY INDIA LACKS A GLOBAL POWER STATUS}

It is obvious that to become a regional hegemon, one has to believe in an expansionist policy that means expanding across one's territory and building the most powerful state in one's region. In addition, the state also has to check the power of the other states in its region for dominance. No doubt, India practices the expansionist policy in its region to dominate weak states, however, China and Pakistan also have projected their military might across South Asia for the same reason.

In South Asia including China, all the three nuclear states are battling for survival and enthusing for becoming a regional hegemon. It is largely held that hegemons are essentially status quo powers, however, states always conduct a rigorous research for arms build-up to change the behaviour of others or for military and nuclear superiority. 
For becoming regional hegemon or great power for survival, the ideal position is the main element. For instance, it is quite difficult to attack the United Kingdom because of the large body of water that surrounds it. Similarly, one has to cross the mighty oceans to attack the United States. John Mearsheimer (2014) talks about the reasons why the United Kingdom and the United States remained great powers from the last century although fought several deadly wars. He is of the view that mighty oceans are the great hindrance for states to attack both superpowers. The other factors include a strong economy, technology, large population, huge conventional force, strategic nuclear force, and clever strategy to win wars. Furthermore, both the US and the UK passes bucks to others states in order to check the power of potential hegemons in Europe and Asia.

The US adopted numerous policies in the past as an offshore balancer to check the potential hegemons in Asia like China, Japan, and Russia. Japan has now strong ties with the US, therefore, it is not a potential rival to the US, however, both China and Russia after their rapid industrialization and arms build-up have challenged the US's hegemony or interests in Asia particularly Northeast Asia.

India, which lacks, a great/global power status due to multiple factors determinately ties with the US and Israel in order to counter China and Pakistan in South Asia. Ironically, it is not actually India but the US which confronts a potential hegemon China in South Asia by preferring buck-passing to India rather than directly confront China's threat to the US.

Although India is surrounded by water and mountains, it lacks an ideal position to become a regional hegemon. For instance, India, Pakistan, and China are vulnerable to each other due to unresolved territorial disputes with close borders. There are fewer chances to thwart a major collision after accidentally missiles were launched against each other. Surprisingly, the deadly missiles loaded with nukes would travel in a few minutes to reach the target location for maximum destruction.

It has been accepted by the realists as well as by neo-realists that a strong economy, large population, the mighty conventional force has been the driving force for winning wars in the past and will continually shapes the security policies of states in future. No doubt, India has a strong conventional force but due to an unfavourable geo-strategic location surrounded by potential/regional hegemon like China and nuclear rival Pakistan, India is vulnerable to attack easily from outsiders. When we scroll the dusty pages of history, we come to know how Afghans, Mughals, and East India Company easily captured Indian territory and wars were fought to achieve their goals. Currently, though India has a strong army to protect its territory, China and Pakistan always challenge its security through infiltration and sub-conventional conflicts.
Vipin Narang (2014) is of the same view that states that share an unchecked land border have more fear than those buffed by impassable terrain. Narang $(2014,77)$ states that Pakistan's asymmetric escalation posture rests on its weak conventional strength than India. There is no strong natural obstacle that can stop all the three states from not attacking each other and the conventionally superior proximate threat is always in the minds of Pakistani policy-makers that is why first-use-policy of nukes has been adopted by Pakistan to respond a conventional attack from India.

It is also true that India's strong conventional force failed to work as a deterrent for Pakistan and China. It seems that both nuclear and conventional force failed to bring stability to the region. It is clear from this point of view that India needs a vast resource to become a regional power against its primary envisaged threats (both internal and external). However, the better suitable solution is to resolve the disputes.

Despite India pass the buck to a weak state like Afghanistan to counter Pakistan, it might not dominate the region due to Pakistan's ties with the United States and China. Similarly, China is nascent as a key player in Afghanistan by offering Afghan leader $\mathrm{Mr}$ Ghani to join CPEC. Reciprocally, India's ambition to connect with Afghanistan through road needs Pakistan's approval which seems difficult rather impossible that Pakistan will offer its territory.

It is a prerequisite to have a strong economy for achieving the status of great power or regional hegemon. Similarly, it is vital to have a peace and order inside the state in order to use the resources for balancing potential hegemon/rival in one's area, however, the case is dissimilar with India, the unrest in Kashmir and eastern states have resulted in the conversion of India's wealth for curbing the violence in these areas.

Apart from these above-mentioned problems, the majority of the people happen to live below the poverty line in India. The great powers like the US, the UK, France, Germany, and Japan have provided great opportunities for their people to progress and achieve a high standard of living through higher education and jobs. Recently, India ranked 100th out of 119 countries on global hunger index ahead of Pakistan but behind North Korea, Bangladesh, Iraq, Sri Lanka, Nepal, Myanmar, and China (The Hindu, 2017). The zeal to become a nuclear weapon power has forced India to channelize its resources for military purposes. However, the nuclear weapons acquisition is not enough to claim itself a great power and nukes did not help India to win the seat at the UN Security Council. Similarly, China's veto is important for the same.

Although India claimed that its nuclear programme is indigenous, nevertheless, there are enough reports that provide a detailed information about the foreign assistance (nuclear reactors and fuel) for India's nuclear programme. The nuclear equipment to conventional arms, strategic air 
bombers to missile defence system has been supplied by the foreign states to India, one can hardly imagine how much money in return India has paid. M. V. Ramana (2012) rejected so-called indigenous India's nuclear programme.

Currently, India is not in a position to balance China in strategic nuclear force and conventional might due to an economic and military gap. Undoubtedly, both states have become the fastest developing economy in the world, however, the size of Indian economy (4.99 trillion) is lower than the size of China (\$US13.39 trillion in terms of PPP). China's economy is over four times bigger but India managed to overtaken its GDP (7.5\%) in 2018 as compared to the GDP of China (6.5\%). Rudroneel Ghosh (2018) argues that China's economic base is so huge that it can still add more to its economy than India even with a lower growth rate. Former RBI governor, Raghuram Rajan argues that India has to improve an infrastructure and built out construction for the growth of the country (Singh. 2018). Rajan said that India is dignified to achieve a higher growth, 'India has a lot to do to get there but it doesn't have a deep constraint in reaching there. It has to make sure it doesn't go autocratic on the way but it has all the elements to reach there' (Singh, 2018). Rajan also pointed out that an enormous part of Chinese growth and manufacturing growth has been much better logistics, access to ports and roads, something 'which India doesn't have' (Singh, 2018). The Study understands that the flawed economic policies should be avoided like demonetisation in 2016 due to which India's GDP slowed down in 2017. Also, it is held that Goods and Services Tax (GST) rollout was responsible for slowing down of Indian GDP (Singh, 2018).

The great source of alarm is that the three nuclear states (India, Pakistan, and China) have more potential conflict situations due to three dyads across which war might break out between the three belligerent states. The imbalances of power and the potential for miscalculation might enforce one state to attack another state. For instance, India-Pakistan wars, India-China territorial clashes, and infiltration. That is why Mearsheimer (2014) is worried about the unbalanced multipolar world where chances of wars are likely.

The study understands that extended conflicts are the biggest obstacle to India for becoming a regional hegemon and its inability to tackle the insurgency thwarted its ambition to achieve a great/global power status. In a nutshell, it is the United States as an offshore balancer checking the power of the two nuclear states (India and Pakistan) in South Asia through hyphenation, dehyphenation, dual-hyphenation policies and buck-passing to India to counter China.

\section{HOW TO CATCH-UP GROWTH}

India's biggest advantage is that it is a democratic state but until and unless democratic principles are not properly implemented, the growth is impossible. Elizabeth Hanson argues that the image of India as a poor country is sharp and clear, its image as a democratic state is more blurred (Palit, 2017, 297). The stable democracy, well developed private sector, relatively entrenched legal system, freedom of speech, and rule of law in World Banks governance indicators are pivotal for growth (Srinivasan, 2006, 37263727). T. V. Paul $(2014,10)$ argues that legitimacy has become more important to state-building after World War II. Paul $(2014,10)$ further argues that legitimacy can come from a combination of democracy and welfare, trade and investment and to provide people with clear benefits. India should avoid wasting money on building needless statues which cost about thousands of crores of rupees (Agarwal, 2018) rather than to develop and implement policies in order to provide collective goods such as security, order, and welfare to its citizens in a legitimate and effective manner (Paul, 2014, 12).

The two economists, Acemoglu and Robinson (2013) are worried about the exclusive political institutions in China although it has adopted some form of inclusive economic institutions. The two economists argued that after some economic prosperity in China it might eventually fail due to its extractive political institutions. The book Why Nations Fail displayed various reasons for the economic failure of the states in past. The most important reasons for the economic failure was the undermining of inclusive political and economic institutions. Also, in case of states manage to implement the inclusive economic institutions and attain some growth, they might eventually collapse due to their extractive politician institutions (Acemoglu and Robinson, 2013). Thus, both inclusive political and economic institutions are essential for economic prosperity and political stability. Similarly, political scientist, John Mearsheimer (2014) argues that states which want to achieve a global power status should avoid wars and focus on economic development. Similarly, Raghuram Rajan argues that India has to improve the infrastructure and construction development for growth (Singh, 2018).

Although India's global soft power like the IT sector, music, movies, food, writing and authors has been praised across the globe, China is ahead of India in many ways. In case India wanted to surpass China, the British journalist, Martin Wolf (Srinivasan, 2006, 3727 ) in his study 'Why India must do to outpace China' concludes that India's prospects for surpassing China depend on implementing difficult reforms in five pivotal areas: 'deregulation of labour markets and an end to the small-scale sector; revitalisation of agricultural growth; increased investment in infrastructure; elimination of fiscal deficits; and, finally, across-the-board privatisation and further trade liberalisation.'

Paul $(2014,9)$ argues that the measure of success or failure of the state is based on its ability to provide the opportunity for citizens to resolve their disputes with the state. The resolution of Kashmir dispute is also significant for economic growth in India because a lot of resources has been diverted to bring back normalcy in the valley. The 
common project school outlined by Mircea Malitza (2000) is an important theory for conflict resolution and might be beneficial in the context of India and Pakistan. The theory is particularly suited to the resolution of persistent conflicts based on identity, values, and culture (Sridharan, 2015, 81). In practical terms, the theory means finding a common project that can produce common interests, overlay diverging interest, and have minimal cultural, value, or belief considerations. E. Sridharan $(2015,82)$ argues that 'when a state joins a common entity with others, territorial possession becomes less relevant'. In my article 'International Relations Theory and Kashmir Conflict', I assumed that peace does not need nukes and liberal democracy what it needs is bold leadership with the efforts from the respective leaders whether be it monarch type or democratic, in both cases they need to give up their old controversial ideology and formulate the strategy of making decisions that will help in bringing stability in the region.

\section{CONCLUSION}

India does not need a strong nuclear force for deterrence. It should focus on quality rather than quantity of arms in case nuclear deterrence works. Although China is stronger than India, India is still in a position to defend its territory with its current sufficient nuclear triad and conventional force. The current size of India's nuclear arsenal is between 100120 that cannot be described as a small nuclear retaliatory force. Paul $(2014,10)$ argues that unnecessary focus on national security can destroy a state. Interestingly, North Korea's few nukes have deterred the United States to attack Pyongyang. India should primarily focus on economic development and provide incentives to its citizens. China's aggressive behaviour toward India is due to an offensive attitude of the United States in collaboration with India toward China in the South China Sea. Mearsheimer (2014) argues that China's main task is to develop its economy and avoid wars currently. India too should focus on economic development and solve its disputes with China and Pakistan peacefully. India's limited war option against Pakistan under the nuclear umbrella would be catastrophic as Pakistan possesses nukes and cannot be trusted to behave rationally. The study understands that military means is not a suitable solution to solve insurgency. Undoubtedly, India is moving fast in the economic sphere and its global soft power has been praised across the globe, however, recent and the first report of the United Nations Human Rights violations in Kashmir which India calls fallacious has stained the image of India at the international level. Subsequently, India was listed by the United Nations in the shameful list of thirty-eight states for reprisal on rights activists. The study understands that peace and humanitarian approach rather than aggressive and offensive tactics (strategic studies) should be given preference to deal with the turbulence situation in Kashmir and media/reporters especially human rights defenders should not be targeted in a democratic state like India. India should avoid slogans, enforce policies and build strong state machinery to provide incentives to the people. The study concludes that the global power status is a feasible dream; however, India has to learn from its past mistakes (learning by trail or error). The 'crisis learning' might help India to formulate changes in the application of security policies. And finally, the 'imitative learning' from the prosperous states might help India to adopt inclusive democratic principles.

\section{REFERENCES}

[1] Acemoglu, Daron, and A. Robison, James. (2013). Why Nations Fail: The Origins of Power, Prosperity and Poverty. London: Prolife Books Ltd.

[2] Agarwal, Nikhil. (2018, October 31). PM Modi inaugurates Sardar Patel statue: World's tallest statue in 10 points. livemint. Retrieved from https://www.livemint.com/Home-Page/m8hB1BLkb6QUZ IlMk wmESO/Sardar-Patel-statue-inauguration-on-Wednesday-Worldstalle.html.

[3] Chu, Ben. (2017, October 09). What is 'nudge theory' and why should we care? Explaining Richard Thaler's Nobel economics prizewinning concept. Independent. Retrieved from https://www. independent.co.uk/news/business/analysis-and-features/nudge-theoryrichard-thaler-meaning-explanation-what-is-it-nobel-economicsprize-winner-2017-a7990461.html.

[4] Dasgupta, Amit. (2018, June 10). View: India's education system needs urgent rewiring: Are we running out of time?. Economic Times. Retrieved from https://economictimes.indiatimes.com/industry/ services/education/view-indias-education-system-needs-urgentrewiring-are-we-running-out-of time/articleshow/64527494.cms.

[5] Doshi, Vidhi. (2018, July 24). 'What is rape, Mom?': A small town in India grapples with how to protect children. Washington Post. Retrieved from https://www.washingtonpost.com/world/asia_pacific/ what-is-rape-mom-a-small-town-in-india-grapples-with-how-toprotect-children/2018/07/23/e01b5000-4e1c-11e8-85c1 9326c4511033_story.html?noredirect=on\&utm_term=.fd4ab7ec7c31.

[6] Ghosh, Rudroneel. (2018, March 16). The China Comparison: It's foolish to compare apples and oranges. Indiatimes. Retrieved from https://blogs.timesofindia.indiatimes.com/talkingturkey/the-chinacomparison-its-foolish-to-compare-apples-and-oranges/.

[7] Highway, Indira. (2018, October 22). Lip service to labour rights. The Hindu. Retrieved from https://www.thehindu.com/opinion/lead/lipservice-to-labour rights/article25280415.ece?homepage=true.

[8] Indiatimes. (2018, November 09). RBI Data Hints Note Ban Was Utter Failure, More Cash In Market Than Before Demonetisation. Indiatimes. Retrieved from https://www.indiatimes.com/news/india /rbi-data -hints-note-ban-was-utter-failure-more-cash-in-market-thanbefore-demonetisation-356352.html.

[9] Indiatimes. (2017, October 15). PM Modi's 'Give It Up' \& 'Swachh Bharat' Are Examples Of Thaler's Nudge Theory That Won Nobel Prize. Indiatimes. Retrieved from https://www.indiatimes.com/ news/ india/pm-modi-s-give-it-up-swachh-bharat-are-examples-of-thaler-snudge-theory-that-won-nobel-prize-331691.html.

[10] India Today. (2016, October 01). SAARC: Maldives joins India, 4 others in boycott; Pak's isolation complete. India Today. Retrieved from https://www.indiatoday.in/world/story/saarc-summit-maldivesjoins-india-pakistan-isolation-complete-344244-2016-10-01.

[11] Kumar, Arun. (2018, November 08). Two Years after Demonetisation, the Nightmare Continues for India's Informal Economy. The Wire. Retrieved from https://thewire.in/politicaleconomy/demonetisation-two-years-narendra-modi-govt-indiainformal-economy.

[12] Krishna, Sankaran. (2009). The Social Life of a Bomb: India and the Ontology of an "Overpopulated" Society. In Itty Abraham (Eds.), South Asian Cultures of a Bomb (68-88). Bloomington: Indiana University Press.

[13] Krishnan, Aishwarya. (2017, November 13). Demonetization Anniversary: Decoding the Effects of Indian Currency Notes Ban. Economic Times. Retrieved from https://economictimes. India times.com/tdmc/your-money/demonetization-anniversary-decodingthe-effects-of-indian-currency-notes-ban/articleshow/ 61579118.cms. 
[14] Mearsheimer, John. (2014). The Tragedy of Great Power Politics. New York: W. W. Norton \& Company.

[15] Narang, Vipin. (2014). Nuclear Strategy in the Modern Era: Regional Powers and International Conflicts. Princeton: Princeton University Press.

[16] Ninan, TN. (2018, October 20). Modi says India can stun the world in the next industrial revolution. He has a point. The Print. Retrieved from https://theprint.in/opinion/modi-says-india-can-stun-the-worldin-the-next-industrial-revolution-he-has-a-point/137293/.

[17] Palit, Parama Sinha. (2017). Analysing China's Soft Power Strategy and Comparative Indian Initiatives. New Delhi: Sage Publications India Pvt Ltd.

[18] Paul, T. V. (2014). The Warrior State: Pakistan in the Contemporary World. Gurgaon: Random House.

[19] Raja, Rameez. (2017, September 23). Are We Heading towards a Nuclear Winter: A Theoretical Framework. Kafila. Retrieved from https://kafila.online/2017/09/23/are-we-heading-towards-a-nuclearwinter-a-theoretical-framework-rameez-raja/.

[20] Rajagopalan, Rajesh. (2013). Evolution of the Indian Army's Counterinsurgency Doctrine. In Kanti P. Bajpai and Harsh V. Pant (Eds.), India's National Security: A Reader (pp. 25-54). New Delhi: Oxford University Press.

[21] Ramana, M. V. (2012). The Power of Promise: Examining Nuclear Energy in India. New Delhi: Penguin.

[22] Rashid Toufiq, (2011, May 11). Local militancy sees a surge; April had most since Burhan Wani encounter. Hindustan Times. Retrieved from https://www.hindustantimes.com/india-news/local-militancysees-a-surge-april-had-most-since-burhan-wani-encounter/storyjbTRtoNGQUPDPC5AYOK5hP.html.

[23] Saran, Samir. (2018, July 23). India's future as a world power depends on 4 key relationships. World Economic Forum. Retrieved from https: //www.weforum.org/agenda/2018/07/india-powerdemocratic-geostrategic-relationships/.

[24] Singh, Yoshita. (2018, April 13). Comparisons between India and China unfair: Raghuram Rajan. livemint. Retrieved from https://www.livemint.com/Politics/dE5ogMTbpVt0Y907A6ePJM/Co mparisons-between-India-and-China-unfair-Raghuram-Rajan.html.
[25] Sputnik News. (2018, October 23). India, Japan to Sign Maritime Pact to Monitor Chinese Warships in Asia-Pacific. Global Security. Retrieved from https://www.globalsecurity.org/military/library/news/ 2018/10/mil-181023-sputnik02.htm?_m=3n\%252e002a\%252e2413 $\% 252 \mathrm{eks} 0 \mathrm{ao0} 06 \mathrm{avk} \% 252 \mathrm{e} 27 \mathrm{zm}$.

[26] Sridharan, E. (2015). Economic Cooperation and Security Theory, India and Pakistan. In E. Sridharan (Eds.), International Relations Theory and South Asia: Security, Political Economy, Domestic Politics, Identities, and Images (pp. 76-104). New Delhi: Oxford University Press.

[27] Srinivasan, T. N. (2006). China, India and the World Economy. Economic and Political Weekly, 41(34), 3716-3727.

[28] The Dawn. (2018, September 08). More embarrassment for govt as second economist resigns from EAC over Atif Mian's exclusion. Dawn. Retrieved from https://www.dawn.com/news/1431705.

[29] The Logical Indian Crew. (2018, October 17). Central University Teachers May Now Be Dismissed for Speaking Against the Government, Says UGC Order. The Logical Indian Crew. Retrieved from https://thelogicalindian.com/news/teachers-can-not-criticisegovernment/

[30] The Times of India. (2008, October 01). IMF appoints India-born Gita Gopinath as Chief Economist. Times of India. Retrieved from https://timesofindia.indiatimes.com/business/india-business/imfappoints-india-born-gita-gopinath-as-chief-economist/articleshow/ $66034263 . \mathrm{cms}$.

[31] UN Human Development Index. (2018, September 14). India ranks 130 on 2018 Human Development Index. UNDP. Retrieved from http://www.in.undp.org/content/india/en/home/sustainable-develop ment/successstories/india-ranks-130-on-2018-human-developmentindex.html.

[32] Vanaik, Achin. (2015). After the Bomb: Reflections on India's Nuclear Journey. New Delhi: Orient Blackswan.

[33] Waltz, Kenneth N. (1981). The Spread of Nuclear Weapons: More May Better. Adelphi Papers, 171, 1-32. 